\title{
The Quality Assessment of Structure of Simple House in Gowa Sari Residential, Bantul Regency
}

\author{
Dwi Kurniati1 ${ }^{1, *}$, Restu Faizah ${ }^{2}$ \\ ${ }^{1}$ Department of Civil Engineering, Universitas Teknologi Yogyakarta, Indonesia \\ ${ }^{2}$ Department of Civil Engineering Universitas Muhammadiyah Yogyakarta, Indonesia \\ *Corresponding author. Email: dwii.kurniatii@gmail.com
}

\begin{abstract}
Bantul Regency is one of the districts in The Special Region of Yogyakarta. In 2006, Bantul experienced an earthquake that took many lives, one of the causes of which was to be hit by a house. Home is every human being's basic need. A good house has an interconnection between each element, both structural and non-structural elements. The purpose of this study is to assess the structural and non-structural elements as well as the quality of the implementation of PUPR guidelines in Gowa Sari Bantul housing, Yogyakarta. This method of research is a quantitative description. The results of the assessment get a level of untidiness of sloof work $10 \%$, foundation $2.5 \%$, main column $12.5 \%$, connection $2.5 \%$ and truss $12.5 \%$, with a construction feasibility rate of $60 \%$. It can be concluded that Gowa Sari housing has technically followed the applicable development rules and is declared habitable.
\end{abstract}

Keywords-Assessment, House, PUPR, Quality, Structure

\section{INTRODUCTION}

Bantul is one of the districts located in the Special Region of Yogyakarta. Having an area located right on the southern coastline of Java Island makes Bantul regency very vulnerable to various natural disasters, one of which is earthquakes. Special Area of Yogyakarta has one fault that stretches from the north side of Prambanan Temple to the south coast of Bantul Regency, this fault is known as Opak Fault [1]. The movement of Opak Fault in 2006 caused a catastrophic earthquake in Bantul and its surrounding area. It caused many fatalities as well as property especially house buildings that do not have good structure construction. The rocky and porous natural conditions located south of Bantul City became the basis of this research. The focus of the research is in The Gowa Sari Residential Area of Bantul Regency. Gowa sari Residential Area is located in Pajangan Village, Bantul Regency, Special Region of Yogyakarta. The rise of housing development makes academics have to think hard, about how to educate citizens that a good home is a house that has an attachment to every structural and nonstructural element. So in the event of an earthquake the building will still stand at least until the house owner leaves the house and the building cannot be immediately collapsed. This housing has about 400 units with the same total type of $36 \mathrm{~m}^{2}$. The construction of this typical simple house wall became one of the responsibilities of the Ministry of Public Works and Public Housing, this was proven by the issue of the Simple House Construction Guidelines.

The purpose of this study is to assess the structural and non-structural elements as well as the quality of the implementation of PUPR guidelines in Gowa Sari Bantul housing, Yogyakarta. This form is adapted from FEMA and the Simple Home Construction Guidelines issued by the Interior Ministry. Quantification is carried out on structural and non-structural elements including foundations, sloofs, beams, columns, roof frames, concrete mixtures, reinforcing, walls, and roofs. The data analysis was assessed with a scale of 1 to $100 \%$ on less, medium, and high feasibility. So get the results in the form of recommendations from the subsidy house structure. The results of this study are the neatness of the foundation structure 5\%, sloof 5\%, main column $5 \%$, connection $5 \%$ and truss $5 \%$, and for non-structural elements i.e. wall with a percentage of $4 \%$. The eligibility for this subsidized house gets the figure of $71 \%$. It can then be concluded that the structure of a subsidized house building has followed the prevailing rules and is declared structurally feasible [2].

It is well known that Indonesian islands are located in areas prone to natural disasters, such as earthquakes, volcanic eruptions, tidal wave floods (tsunamis), and landslides. This is because the Indonesian archipelago is located at the joint of three interconnected active tectonic plates, namely the Indian- Australian Ocean Plate, the Eurasian Plate, and the Pacific Plate. North Maluku is located on three large plates namely the Eurasian plate, the Pacific plate and the Indo Australian plate which affects the level of earthquake because it is at a point of Halmahera that can cause a devastating earthquake. The tectonic arrangement of Maluku Sea is unique. This is the only example of an active collision in the world that sinks an ocean basin through subduction in two directions. The Maluku Sea Plate was sunk by two micro 
tectonic plates, the Halmahera Plate and the Sangihe Plate. Its complexity is now known as the Maluku Sea Collision Zone. This research aims to identify and know the damage of simple house buildings typical of walls due to earthquakes that occurred in East Gane District of South Halmahera Regency. The results showed that all types of houses located in Yomen Village and Sekli East Gane District of South Halmahera Regency do not use good standards such as column size, foundation, sloof, walls, ring balks, roof, truss, and reinforcement bar detail at column joint that are not good and do not meet Indonesia's National Standards for earthquakes and earthquake resistant house building guidelines[3]. The evaluation of mitigation for residential building on Doom Island showed that it has not met the requirements for resistant buildings earthquake. This shows awareness of the importance of building an earthquakeresistant building structure that have not been truly understood by the people in Doom Island. It may increase level of damage and loss of life due to earthquake and it needs a serious handler [4].

\section{RESEARCH METHOD}

\subsection{Data Collection}

Data collection used in this research were primary data and secondary data. Primary data was data obtained directly in the field based on observations, interviews, and documentation. The main data used in this study is the assessment of other structural elements of the foundation, sloof, columns, beams, roof frames, concrete mixtures and reinforcement used. Non-structural elements consist of walls and roofs. The secondary data namely the Simple House Building Guidelines is by the Ministry of Public Works and Public Housing (PUPR) year 2017 [5].

\subsection{Analysis Data}

Data analysis consists of several stages such as data processing and then concluding. The first thing to do is to take data in the field with the help of a form designed from the Simple House Building Guidelines issued by the Ministry of Public Works and Public Housing (PUPR). This form contains an assessment of the elements of the structure namely the foundation, sloof, columns, beams, roof frame, concrete and reinforcing mixture, as well as on the nonstructural elements of the walls and roof. After retrieving the data, the next stage is scoring. The assessment form contains 40 types of questions, the scoring classification is divided into three i.e. 1 for "Yes", 0.5 for "Less" and 0 for "No". The percentage of untidiness is divided into three criteria namely $1 \%$ to $30 \%$ "light", $31 \%$ to $60 \%$ "Medium", and $61 \%$ to $100 \%$ "Weight". As for the classification of recommendations divided into 3 clusters namely, $1 \%$ to $35 \%$ Category of "small" recommendation means it requires improvement and strengthening of the structure, $36 \%$ to $70 \%$ goes into the "medium" classification and is recommended to be applied, and the latter is $71 \%$ to $100 \%$ which means the residential house structure has had a "very good" construction so it is highly recommended and very habitable. This type of assessment can be seen in Table 1 .

\section{RESULTS AND DISCUSSIONS}

A type of $36 \mathrm{~m}^{2}$ house with a length of 6 meters and a width of 6 meters was studied. The site plan can be seen in Figure 1. The home face can be seen in Figure 2, and the main data from the observed results can be seen in Table 2 .

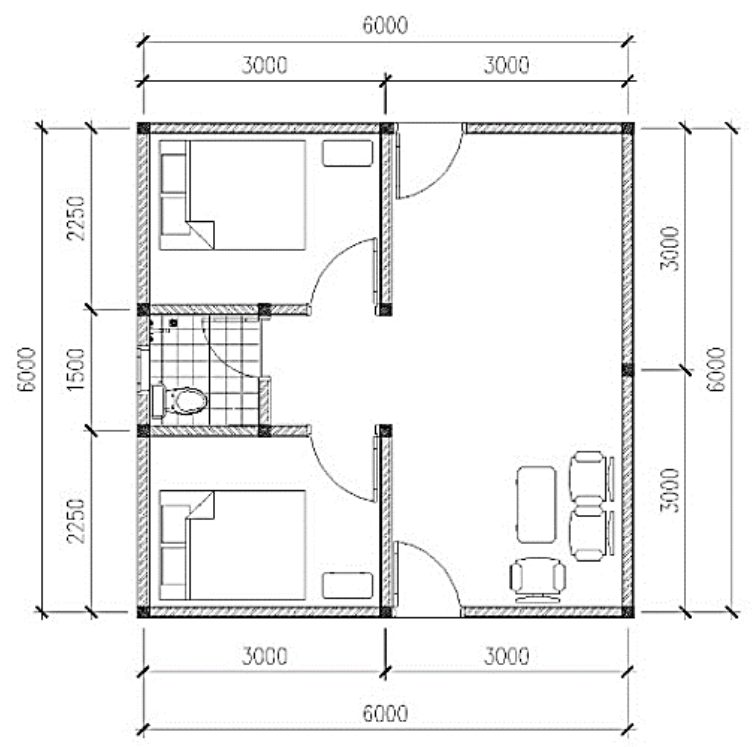

Figure 1. Site Plan

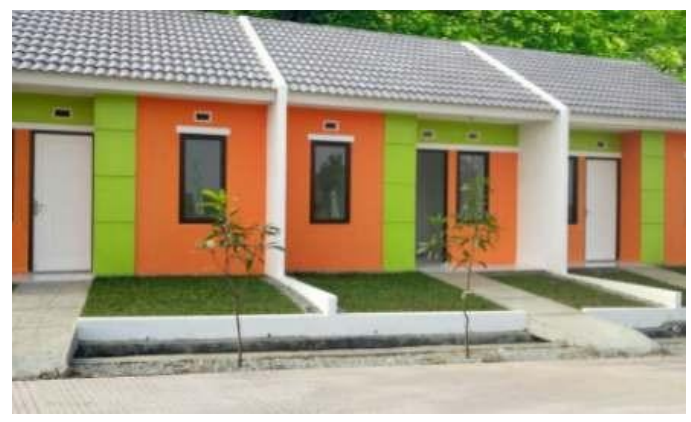

Figure 2. Home Face. 
Table 1. Form Assessment

\begin{tabular}{|c|c|c|}
\hline NO & \multicolumn{2}{|l|}{ OBSERVATION } \\
\hline A & Plan images & 1. Development based on plan images \\
\hline B & Floor plan & $\begin{array}{l}\text { 2. Symmetrical Floor Plan } \\
\text { 3. No protrusion }>25 \% \text { of the largest floor plan size }\end{array}$ \\
\hline $\mathrm{C}$ & $\begin{array}{l}\text { Foundation Sloof } \\
\text { Column }\end{array}$ & $\begin{array}{l}\text { 4. Depth according to the design manual }(\mathrm{min} .60 \mathrm{~cm}) \\
\text { 5. Width according to the design manual }(\mathrm{min} .60 \mathrm{~cm}) \\
\text { 6. Column plain bars implanted in foundations as deep as } 40 \mathrm{~d} \text { or more } \\
\text { 7. Hard times stone or hard white stone } \\
\text { 8. Mortar mixture for speciment } 1 \text { cement }: 4 \text { aggregates }\end{array}$ \\
\hline $\mathrm{D}$ & $\begin{array}{l}\text { Wall } \\
\text { Ring balk } \\
\text { Reinforcement bar } \\
\text { at joint of beam and } \\
\text { column }\end{array}$ & $\begin{array}{l}\text { 9. Minimum size according to the design manual (min. } 15 \mathrm{~cm} \times 20 \mathrm{~cm}) \\
\text { 10. Elongated plain bars according to the design manual }(\mathrm{min} .4 \mathrm{~d} 10) \\
\text { 11. Twisted bars according to the design manual (min. D8 }-150) \\
\text { 12. There are anchors to the foundation } \\
\text { 13.Is concrete sloof balk (not hollow) } \\
\text { 14. Concrete mixture } 1 \mathrm{pc}: 2 \text { sand }: 3 \text { gravel }\end{array}$ \\
\hline $\mathrm{E}$ & $\begin{array}{l}\text { Connection } \\
\text { of truss }\end{array}$ & $\begin{array}{l}\text { 15. Minimum size according to the design manual }(\min .15 \mathrm{~cm} \times 15 \mathrm{~cm}) \\
\text { 16. Elongated plain bars according to the design manual }(\min 4 \mathrm{~d} 10) \\
17 \text {. Twisted bars according to design manual (min } \mathrm{d} 8-150) \\
\text { 18. Does the concrete mix column good (not hollow) } \\
\text { 19. Concrete mixture } 1 \mathrm{pc}: 2 \mathrm{sand}: 3 \text { gravel }\end{array}$ \\
\hline $\mathrm{F}$ & $\begin{array}{l}\text { Floor plan } \\
\text { Foundation }\end{array}$ & $\begin{array}{l}\text { 20. Wall area bordered by beams, sloof and columns no more than } 9 \mathrm{~m}^{2} \\
\text { 21. There is an anchor to the column } \\
\text { 22. Mortar mixture for specimen } 1 \mathrm{pc}: 4 \text { sand }\end{array}$ \\
\hline G & $\begin{array}{l}\text { Sloof } \\
\text { Column }\end{array}$ & $\begin{array}{l}\text { 23. Minimum size according to the design manual }(\min .12 \mathrm{~cm} \times 15 \mathrm{~cm}) \\
\text { 24. Elongated plain bars according to design manual }(\min 4 \mathrm{~d} 10) \\
\text { 25. Twisted bars according to the design manual (min } \mathrm{d} 8-150) \\
\text { 26. Is the mix of concrete ring balk good (not hollow) }\end{array}$ \\
\hline $\mathrm{H}$ & Wall & $\begin{array}{l}\text { 27. Concrete mixture } 1 \mathrm{pc}: 2 \text { sand }: 3 \text { gravel } \\
28 \text {. The plain bar at the end corner is } 40 \mathrm{~d} \text { or } 30 \mathrm{~d} \text { long with hooks. }\end{array}$ \\
\hline I & & 29. There is an overlap min $40 \mathrm{~d}$ \\
\hline $\mathrm{J}$ & $\begin{array}{l}\text { Ring balk } \\
\text { Reinforcement bar at } \\
\text { joint of beam and } \\
\text { column } \\
\text { Connection of truss }\end{array}$ & $\begin{array}{l}\text { 30. There are fencing for curtains } \\
\text { 31. Is the concrete mix of slanted beams good (not hollow) } \\
\text { 32. Minimum size according to the design manual (min. } 12 \mathrm{~cm} \times 15 \mathrm{~cm}) \\
\text { 33. Elongated plain bars according to the design manual }(\min 4 \mathrm{~d} 10) \\
\text { 34. Twisted bars according to the design manual (min } \mathrm{d} 8-150) \\
\text { 35. There is a wind bond }\end{array}$ \\
\hline K & Truss & $\begin{array}{l}\text { 36. Minimum wood size } 6 \mathrm{~cm} \times 12 \mathrm{~cm} \\
\text { 37. Connection is sealed } \\
\text { 38. There is a wind bond } \\
\text { 39. There is an anchor on the mount } \\
\text { 40. Dark wood }\end{array}$ \\
\hline
\end{tabular}

Table 2. Structural and Non-Structural Elements

\begin{tabular}{|c|c|c|c|c|c|}
\hline Structure & Description & Data & Structure & Description & Data \\
\hline \multirow{2}{*}{ Foundation } & Angkur to Sloof & $\varnothing 8$ & Practical & Dimensions & $15^{*} 15 \mathrm{~cm}$ \\
& Broken Stone & - & & Reinforcement & $4 \varnothing 8$ \\
& Distance & - & & Twisted T & $\emptyset 8-20 \mathrm{~cm}$ \\
\hline \multirow{2}{*}{ Sloof } & Dimensions & $15^{*} 15 \mathrm{~cm}$ & Beam & Twisted L & $\emptyset 8-20 \mathrm{~cm}$ \\
& Reinforcement & $4 \varnothing 8$ & & Dimensions & $15^{*} 15 \mathrm{~cm}$ \\
& Twisted T & $\varnothing 8-20 \mathrm{~cm}$ & & Reinforcement & $4 \varnothing 8$ \\
& Twisted L & $\varnothing 8-20 \mathrm{~cm}$ & & Twisted T & $\varnothing 8-20 \mathrm{~cm}$ \\
\hline
\end{tabular}




\begin{tabular}{|c|c|c|c|c|c|}
\hline Column & $\begin{array}{c}\text { Dimensions } \\
\text { Reinforcement } \\
\text { Twisted T } \\
\text { Twisted L }\end{array}$ & $\begin{array}{c}15 * 15 \mathrm{~cm} \\
4 \varnothing 8 \\
\varnothing 8-20 \mathrm{~cm} \\
\varnothing 8-20 \mathrm{~cm}\end{array}$ & Truss & $\begin{array}{c}\text { Twisted L } \\
\text { Dimensions } \\
\text { Reinforcement } \\
\text { Twisted T } \\
\text { Twisted L } \\
\text { Dimensions } \\
\text { Reinforcement } \\
\text { Twisted T } \\
\text { Twisted L } \\
\text { Dimensions }\end{array}$ & $\begin{array}{c}\varnothing 8-20 \mathrm{~cm} \\
12 * 15 \mathrm{~cm} \\
4 \varnothing 8 \\
\varnothing 8-20 \mathrm{~cm} \\
\varnothing 8-20 \mathrm{~cm} \\
15 * 15 \mathrm{~cm} \\
4 \varnothing 8 \\
\varnothing 8-20 \mathrm{~cm} \\
\varnothing 8-20 \mathrm{~cm} \\
15 * 15 \mathrm{~cm}\end{array}$ \\
\hline
\end{tabular}

\section{DISCUSSIONS}

Design principles of the building are when:

a) Small earthquake: then structural and nonstructural element of the building will not be damaged.

b) Moderate earthquake: minor damage of nonstructural building may occur, but structural element should not be damaged at all.

c) Biggest earthquake: buildings may suffer damage to structural and non-structural elements but they are not permitted to collapse immediately.

Assessment results can be found in the following explanation.

\subsection{Foundation}

The foundation is placed on hard soil with a depth of at least $60 \mathrm{~cm}$. Material used for foundation structures is made of stone and crashed stone with mortar mixture 1:4.

\subsection{Sloof}

An anchor should be placed in sloof. Bond between anchor and beams will be useful for withstanding earthquakes as lateral force on buildings. The anchor between the foundation and the sloof is a strengthener with a diameter of 1.5 with a distance of $1.5 \mathrm{~m}$. With a sloof size of $15 \mathrm{~cm}$ $20 \mathrm{~cm}$.

\subsection{Columns}

The columns used are at least $15 \mathrm{~cm} \mathrm{x} 15 \mathrm{~cm}$ according to planning. This square-shaped column has four vertical reinforcement rods at least $8 \mathrm{~mm}$ in diameter and a reinforcement bar diameter of at least $8 \mathrm{~mm}$ with non-hollow concrete mixture. With concrete mixture 1pc:2sand:3 gravel.

\subsection{Ring balk}

Ring balk used has qualified from earthquake resistant buildings with a minimum size of $15 \mathrm{~cm} \times 15 \mathrm{~cm}$ with a minimum main reinforcing diameter of $8 \mathrm{~mm}$ and twisted bar diameter of at least $8 \mathrm{~mm}$ with a mix of $1 \mathrm{pc}$ ring balk concrete: 2 sand: 3 gravel. Ring balk as the upper binding beam should be fused with the column and roof frame.

\subsection{Truss}

The length of truss is $5 \mathrm{~m}$, therefore an additional reinforced concrete should be given with a distance of every $1.5 \mathrm{~m}$. A light steel frame is used for truss. Connection between beam, columns should be perfectly bounded.

\subsection{Reinforcement bar}

Each component of the structure in a typical simple house building has met the minimum standards of main diameter and spine and other necessary distances. The remaining bar at each joint are the end of the beam and the column is at least 40D. The required diameter is at least $8 \mathrm{~mm}$.

\subsection{Concrete}

The concrete mixture used should use a mixture of $1: 2: 3$ for cement, sand and gravel. As for mortar mixture should be $1: 4$ for cement and sand.

\subsection{Walls}

The area of the walls is bordered by beams, sloof and columns no more than $9 \mathrm{~m}^{2}$. There should be wall-to- column fencing and mortar mixture for specimen mixture 1:4 on cement and sand.

\subsection{Concrete mixture}

The concrete mixture used should use a mixture of $1: 2: 3$ for cement, sand and gravel. As for mortar mixture should be $1: 4$ for cement and sand.

\subsection{Roof}

The roof used is galvalum sand. This roof is good enough to use, considering the type of roof is quite light and homogeneous with the roof frame. The connection between the roof and the roof frame must be designed in such a way as to withstand the force of the wind that works. 
From the assessment, number of "Yes" from 24 items includes 1 point for picture, 2 points for floor plan, 4 points for foundation, 1 point for sloof, 2 points for column, 1 point for wall, 2 points for ring balk, 1 point for the connection, 5 points for the mountains and 5 points for the truss, up to $60 \%$. The remaining $10 \%$ is other works in the field, and $30 \%$ is less neat work ranging from casting, Twisted bar installation or formist release the percentages "Yes", "No" or "less" can be seen in Figure 3 and Figure 4.

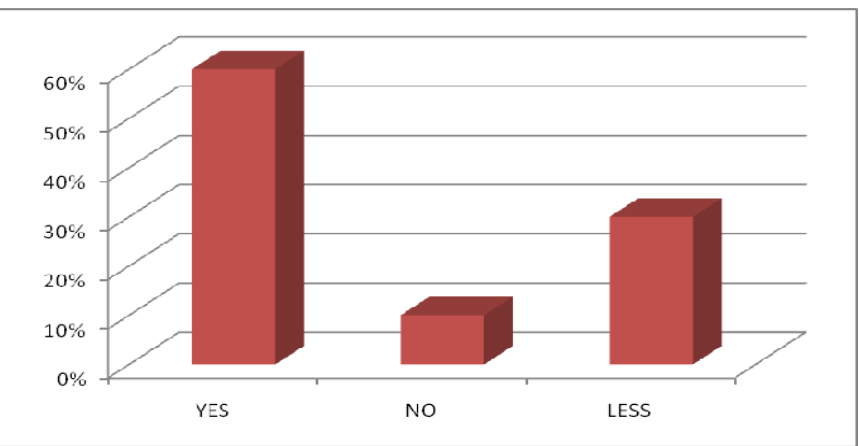

Figure 3. Number of Scoring Results

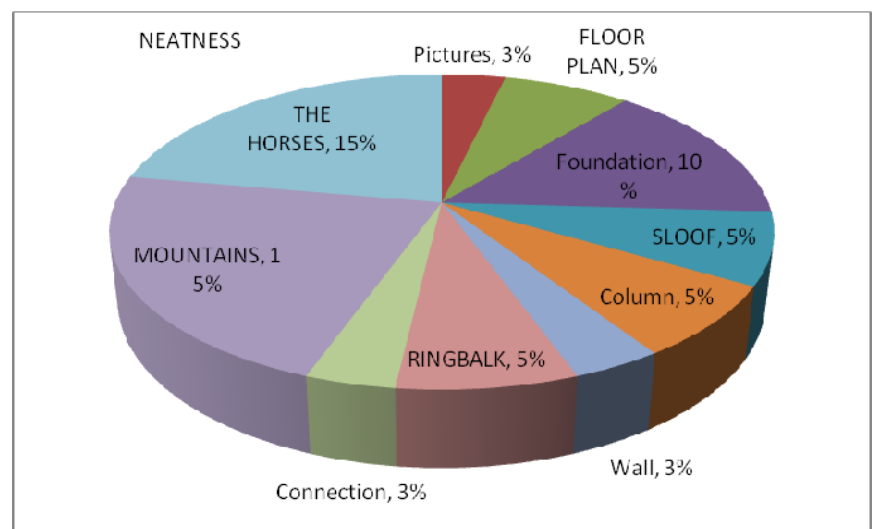

Figure 4. Neatness Score

The percentage of untidiness of the implementation of residential structures in succession occurs in the element of the sloof structure $10 \%$, the foundation $2.5 \%$, the main column $12.5 \%$, the connection $2.5 \%$ and the truss $12.5 \%$. $40 \%$ of elements was categorized not feasible, while $60 \%$ was feasible. This factor will trigger reinforcement bar loss in structural elements. These results can be seen on Figure 5 .

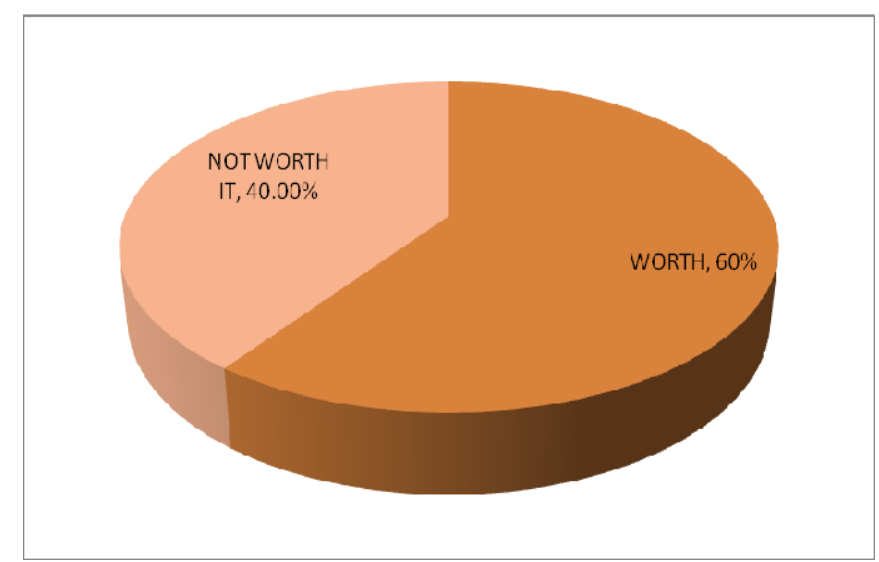

Figure 5. Recommendation of Feasibility

\section{CONCLUSIONS}

Tidiness of structural and non-structural elements needs to be improved, to maintain quality of the reinforcement bars and concrete mixtures to avoid oxidation. The results of the assessment get a level of untidiness of sloof work $10 \%$, foundation $2.5 \%$, main column $12.5 \%$, connection $2.5 \%$ and truss $12.5 \%$, with a construction feasibility rate of $60 \%$ so that it can be concluded that Gowa Sari housing has technically followed the applicable development rules and it is habitable.

\section{REFERENCES}

[1] Rasyid, "5 Fakta Sesar Opak, Patahan Aktif yang Kerap Jadi Penyebab Gempa di Jogja," Merdeka Jateng, 2020.

[2] D Kurniati, "Analysis of Feasibility Study of Houses [Analisa Kelayakan Rumah Sederhana]," J. TAPAK, vol. 10, no. 1, pp. 55-65, 2020, doi: http://dx.doi.org/10.24127/tp.v10i1.1321.

[3] E. Rizky, A.E., \& Tutuheru, "Evaluation of Earthquake Resistant House [Evaluasi bangunan sederhana tahan gempa]," Sipilsains, vol. 10, pp. 41-52, 2020.

[4] M. Bawoleh, W. Mandela, and A. Rusdi, "Evaluation of Structural Mitigation after Earthquakr in Doom, Sorong City [Evaluasi Mitigasi Struktur Bencana Gempa Bumi Di Wilayah Pulau Doom Kota Sorong]," J. Tek. Sipil Ranc. Bangun, vol. 2, no. 2, p. 37, 2019, doi: $10.33506 /$ rb.v2i2.482.

[5] Ministry of Public Housing, Panduan Pembangunan Perumahan Dan Pemukiman Pedesaan. . 